\title{
Civilian Gunshot Injuries: Experience from Sokoto, North-West, Nigeria
}

\section{Oboirien $\mathbf{M}^{*}$, Agbo SP and Adedeji BK}

Department of Surgery, Usmanu Danfodiyo University, Sokoto, Nigeria

\begin{abstract}
Introduction: The Proliferation of small arms in the West African sub-region and the activities of insurgent groups and rustlers have caused renewed interest in Gunshot injuries. We aim to document the trend and outcome of such injuries in our sub-region.
\end{abstract}

Methods: It was a prospective study of cases of gunshot injuries admitted at the University Teaching hospital over a period of 18 months. Parameters analysed included patients' bio-data, region of the body affected, mechanism and source of projectile, clinical presentations and short term outcome. Statistical analysis was done with IBM SPSS 20. Level of significance was $p<0.05$.

Results: A total of 43 patients were seen with a mean age of $33.76 \pm 10.59$. There were $42(97.7 \%)$ males and $1(2.3 \%)$ female. The victims were mostly farmers $(25 \%)$, professional drivers $(13.6 \%)$, Students $(11.4 \%)$. The body region affected were the lower extremity $(36.4 \%)$, upper extremity $(27.3 \%)$, Most of the cases were from armed robbery attack $(77.3 \%)$ and Assaults (13.6\%). Low velocity weapons like Dane guns were the common sources of projectile $95.3 \%$. High velocity weapon like AK 47 was used in $4.7 \%$ of cases. Majority of victims were shot at closed range $(86.4 \%)$ and $79.5 \%$ were stable on presentation. Intervention carried out included wound debridement $(65.9 \%)$, external fixation $(23 \%)$, and chest tube drainage $(9.1 \%)$. The outcome was such that $68.2 \%$ survived without residual deficit while $31.8 \%$ survived with residual deficit.

Conclusion: Gunshot injuries were mainly from armed robbery attack using low velocity weapon with farmers being the most victims. Strict regulations in the acquisition and use of light firearms would reduce the incidence of armed robbery and gun related violence in our sub region.

Keywords: Gunshot injuries; Civilian; Northwest Nigeria

\section{Introduction}

Gunshot injuries (GSI) amongst civilian population are a common phenomenon globally and Nigeria is no exception. The proliferation of small arms in the sub-Saharan Africa coupled with the activities of insurgent groups, cattle rustlers and armed robbers has caused renewed interest in GSI amongst Trauma Surgeons. The aetiology of GSI varies from developed to developing countries and also within the different regions in Nigeria. While terrorism related and Suicidal causes abound as causes of GSI in developed countries, armed robbery attack, accidental discharge and assaults are common causes in developing countries [1]. In 2010, guns took the lives of 31,076 Americans in homicides, suicides and unintentional shootings. This is the equivalent of more than 85 deaths each day and more than three deaths each hour. Also in 2010, 73,505 Americans were treated in hospital emergency departments for non-fatal gunshot wounds. Firearms were the third-leading cause of injury-related deaths in America in 2010, following poisoning and motor vehicle accidents [2] The causes of gunshot injuries in Nigeria like many other African and developing countries include communal clashes, sectarian religious crises, military violence, armed robbery, hunting, political violence, students' cultism activities and rarely sporting and suicidal attempt [3]. Gunshot injuries is reported to be the second commonest cause of death per 1000 in Transkei region of South Africa [4]. Reports on Gunshot injuries from various regions in Nigeria shows that armed robbery attack on highways and at home is the major aetiological factor [5-8].

\section{Patients and Method}

It was a prospective study of cases of gunshot injuries seen and treated at the Trauma Centre of a tertiary hospital in Sokoto, Northwest Nigeria over a period of 18 months from January 2014 to June 2015. An observer administered questioner was used to gather data on patients' bio-data, region of the body affected, mechanism and source of projectile, clinical presentations and outcome. Cases of gunshot injuries that died before presentation were excluded and those that presented for treatment were usually accompanied by law enforcement agents. Gunshot injuries were notifiable cases and were reported to the supervising Consultant. Statistical analysis was done with IBM SPSS 20 and level of significance set at $\mathrm{p}<0.05$ with results presented in tabular and graphical forms.

\section{Results}

There were a total of 43 patients seen with age range of between 15 and 70 years with a mean age of $33.76 \pm 10.59$. Majority of those affected were between the ages of 21 and 30 years (46.5\%) followed by those between 31 and 40 years (30.3\%) (Figure 1). There were $42(97.7 \%)$ males and $1(2.3 \%)$ female (Figure 2 ). The victims were mainly farmers (26\%), professional drivers (14\%), Students (12\%) (Figure 3). The body regions affected were the lower extremity (37.2\%), upper extremity (25.6\%), Head and Neck (9.3\%), more than two regions (11.6\%) (Table 1). The nature of the extremity injuries included soft tissue, fractures and fracture-dislocation. Majority of the cases were from armed robbery attack (79.1\%) and Assault (11.6\%), accidental discharge (7.0\%) (Figure 4). Low velocity weapons like Dane guns were the common sources

*Corresponding author: M Oboirien, Department of Surgery, Usmanu Danfodiyo University, Garba Nadama Road, Sokoto, Sokoto 84000, Nigeria, Tel: 2348067893799; E-mail: moboirien@yahoo.com

Received December 16, 2016; Accepted January 04, 2016; Published January 08, 2016

Citation: Oboirien M, Agbo SP, Adedeji BK (2016) Civilian Gunshot Injuries: Experience from Sokoto, North-West, Nigeria. J Trauma Treat 5: 285. doi:10.4172/2167-1222.1000285

Copyright: ( $) 2016$ Oboirien M, et al. This is an open-access article distributed under the terms of the Creative Commons Attribution License, which permits unrestricted use, distribution, and reproduction in any medium, provided the original author and source are credited. 
Citation: Oboirien M, Agbo SP, Adedeji BK (2016) Civilian Gunshot Injuries: Experience from Sokoto, North-West, Nigeria. J Trauma Treat 5: 285. doi:10.4172/2167-1222.1000285

Page 2 of 3

of projectile in $95.3 \%$. High velocity weapon like AK 47 were used in $4.7 \%$ of cases. Majority of victims were shot at close range $(86.4 \%)$ and $79.5 \%$ were stable on presentation. Intervention carried out included wound debridement (69.8\%), external fixation (18.6\%), and chest tube drainage (9.3\%). The outcome was such that $67.4 \%$ survived without residual deficit while $32.6 \%$ survived with residual deficit. No death was recorded on admission. Chi square test showed a statistically significant

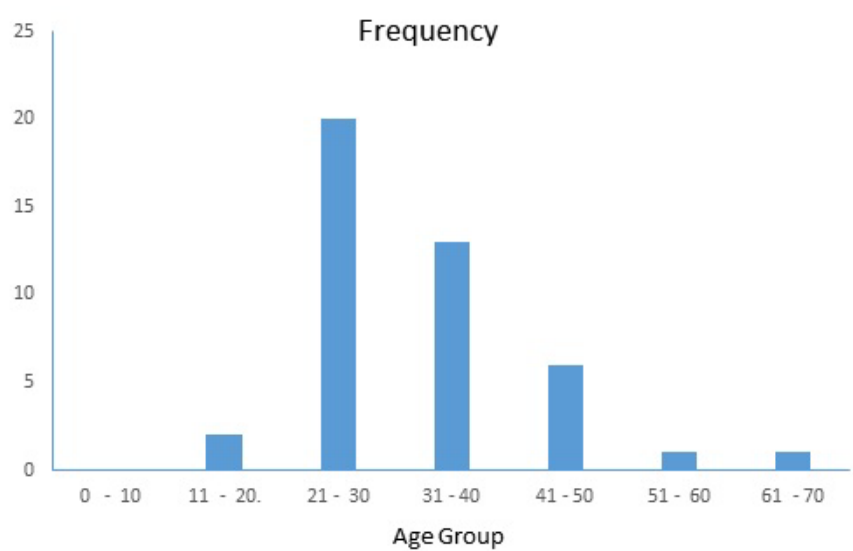

Figure 1: Age distribution of GSI victims.

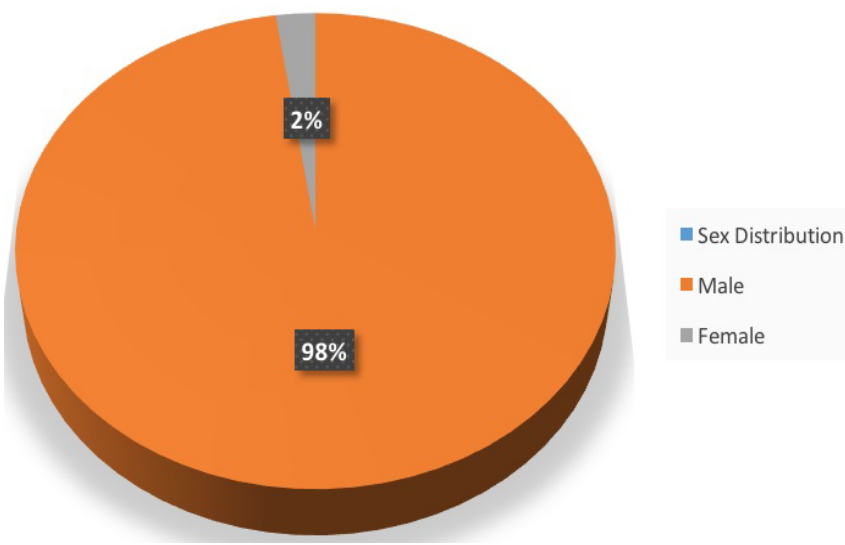

Figure 2: Sex Distribution of victims.

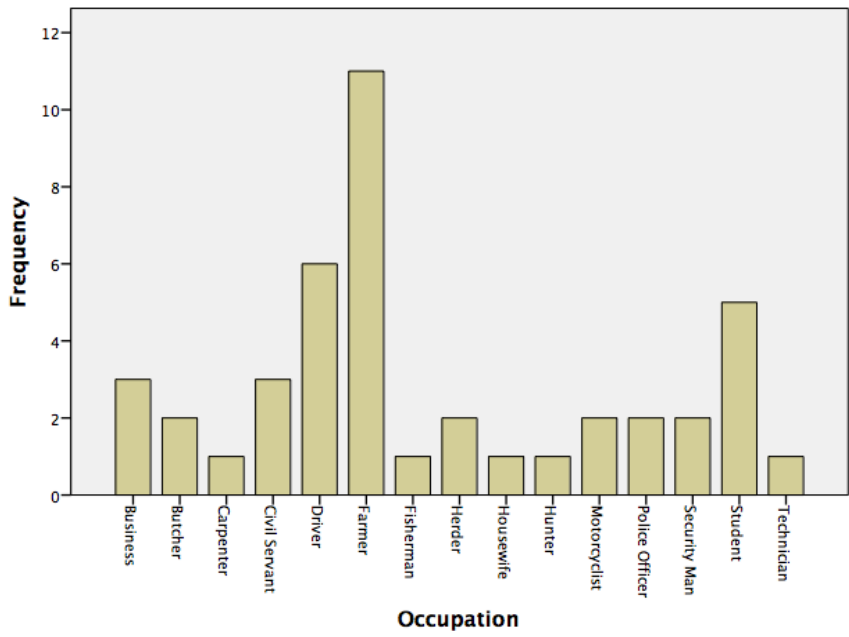

Figure 3: Occupation of victims

\begin{tabular}{|l|c|c|}
\hline Body Region & Frequency & Percentage \\
\hline Head and Neck & 4 & 9.3 \\
\hline Chest & 3 & 7 \\
\hline Upper Extremity & 11 & 25.6 \\
\hline Abdomen & 3 & 7 \\
\hline Lower Extremity & 16 & 37.2 \\
\hline Pelvis & 1 & 2.3 \\
\hline More than two regions & 5 & 11.6 \\
\hline Total & 43 & 100 \\
\hline
\end{tabular}

Table 1: Region of body affected.

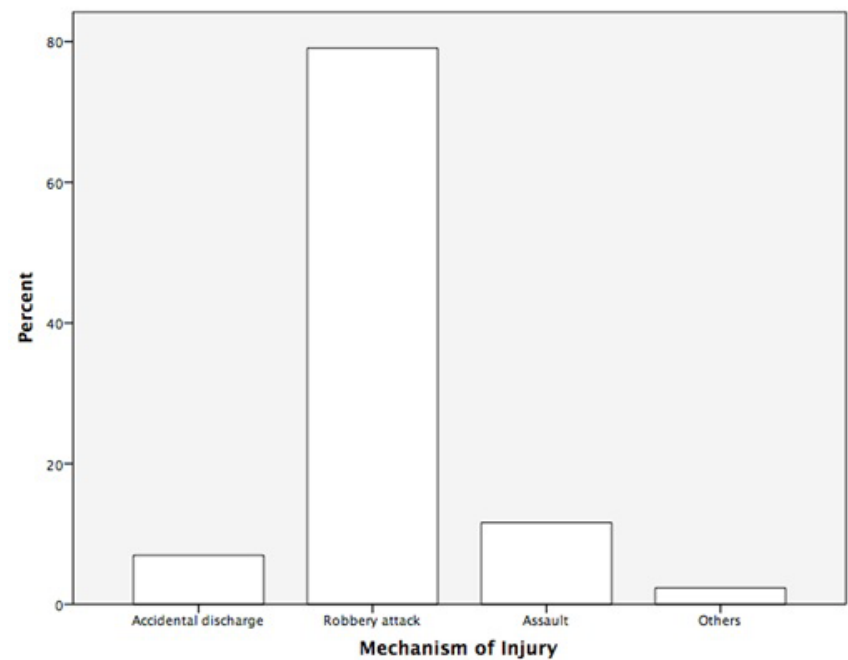

Figure 4: Mechanism of gunshot injuries.

\begin{tabular}{|c|c|c|c|c|c|}
\hline & \multicolumn{5}{|c|}{ Outcome } \\
\hline & $\begin{array}{l}\text { Survived with } \\
\text { residual Survived } \\
\text { with no deficit }\end{array}$ & $\begin{array}{c}\text { Residual } \\
\text { deficit }\end{array}$ & Total & Chi-Square & P-value \\
\hline \multicolumn{6}{|l|}{ Source of Projectile } \\
\hline High velocity & 2 & 0 & 2 & \multirow{2}{*}{4.24} & \multirow{2}{*}{0.04} \\
\hline Low velocity & 12 & 29 & 41 & & \\
\hline \multicolumn{6}{|l|}{ Distance from gunshot } \\
\hline Close range & 11 & 28 & 39 & \multirow{2}{*}{3.53} & \multirow{2}{*}{0.06} \\
\hline Long range & 3 & 1 & 4 & & \\
\hline \multicolumn{6}{|l|}{ Intervention } \\
\hline Chest tube & 0 & 4 & 4 & \multirow{5}{*}{7.91} & \multirow{5}{*}{0.10} \\
\hline Debridement with cast & 1 & 0 & 1 & & \\
\hline External fixation & 2 & 6 & 8 & & \\
\hline Wound debridement & 10 & 19 & 29 & & \\
\hline Wound Exploration & 1 & 0 & 1 & & \\
\hline
\end{tabular}

Table 2: Cross tabulation of Outcome with Source of missile, Distance from gunshot and intervention.

relationship between the source of projectile $(\mathrm{p}=0.04)$ and outcome while there was no statistical significant between the distance from the source of projectile $(\mathrm{p}=0.06)$, and intervention $(\mathrm{p}=0.10)$ with outcome (Table 2). Complications of wound infections, nerve palsy was seen.

\section{Discussion}

The study area which is located in the extreme North western part of Nigeria has been relatively peaceful and crime free. The 43 patients seen in our institution over an 18 months' period is comparable to the numbers in some other cities in Nigeria over a similar time frame. This obviously does not give a true incidence of Gun related violence in our 
sub-region as the study was a single centre based study and it did not include those that died before reaching the hospital. Nigerian extant laws require that police report, are produced in cases of gunshot injuries hence most are usually managed in government owned institution. In Abeokuta, South west, Nigeria, 46 patients were seen over a 2 year period [1]. The higher male preponderance is our study was similar to that seen in other studies in cities like Abeokuta, North west, Maiduguri and kano, North east and North west respectively $[1,3,5,6]$. The overwhelming sex discrepancies in favour of men is a reflection of the cultural norms where men who are bread winners dominate all spheres of life. The predominant age group seen in our study was similar to that in other parts of Nigeria. The reasons for this is not far fetched as these are the most productive age group and are more involved in sociopolitical and economic activities.

Armed robbery attacks accounted for most of the cases of Gunshot injury in our study. This was also the findings in Kano, Irrua and Maiduguri but was in contrast with predominance of stray bullet/ accidental discharge incidents found in Calabar, South-south, Nigeria [6-9]. Proliferation of small arms, dwindling economic prospect and job losses coupled with the activities of insurgents in the North eastern part of Nigeria has resulted in the activities of armed bandits and kidnappers. Majority of the victims involved in gun shot injuries were farmers and professional drivers. Farming is a major occupation of the people in this region and they are thought to be economically empowered and they are therefore more likely to be victims of armed robbery attacks. Another explanation for the high incidence in farmers could be the recurrent clashes between herdsmen and farmers over grazing rights and cattle rustling. Highway armed robbery attacks involved commercial drivers who are dispose of their belongings and money. Other aetiological factors noted were assault from communal dispute. Accidental discharge from poor weapon handling was seen in police officers and this involved high velocity weapons.

The pattern of injuries noted involved mainly the extremities and this would indicate that the intention of the assailants was to maim rather than kill. This was also the findings in Abeokuta, Maiduguri, kano, Calabar, Irrua, and Gombe studies [1,7,9-12], but differs from findings from Lagos and Benin in Nigeria and Durban, South Africa where abdominal injuries predominated [13-16]. It should be noted that we did not witness any religious riots during the period this study was carried out hence the pattern of injuries were predictable. Craniofacial injuries have been reported following civil unrest and riots as intention are meant to kill [17].

Most of the victims where shot by low velocity weapon and this had a statistical significance on the outcome. High velocity weapons have greater kinetic energy and consequent potential to destroy tissue as a result of the temporary cavitation induced once the bullet becomes deformed. Bullet fragmentation and bony fractures are predictors of increased wound severity whereas low velocity bullet causes damage limited to the bullet's path mainly as a result of localized crush injury $[18,19]$. The distance from the source of weapon and the intervention done had no statistical significance on the outcome. Life and limb saving procedures like chest tube insertions and external fixations were amongst the interventions carried out since most of the injuries were to the extremities. Outcome was good as those that had residual deficit in the short term had wound infection, nerve palsy and chronic osteomyelitis.

\section{Conclusion}

Gunshot injuries are a source of violence in our sub region targeting economically endowed individuals. Although the outcome appears good with low velocity weapons, strict regulations in the acquisition and use of light firearms would reduce the incidence of armed robbery and gun related violence in our sub region.

\section{References}

1. Aigoro N, Abass G (2013) Epidemiology of Gunshot Injuries in Abeokuta, Southwest Nigeria. The Internet Journal of Orthopaedic Surgery 20.

2. Nat'l Ctr. for Injury Prevention \& Control, U.S. Centers for Disease Control and Prevention, Web-Based Injury Statistics Query \& Reporting System (WISQARS) Injury Mortality Reports, 1999-2010, for National, Regional, and States (2012), (hereinafter WISQARS Injury Mortality Reports (1999-2010).

3. Ogunlusi JD, Oginni LM, Ikem IC, Olasinde AA, Hamilton OG, et al. (2006) Gunshot Injuries in a Nigerian Hospital. Nigerian $\mathrm{J}$ of Ortho and Trauma 5 : 34-37.

4. Meel BL (2004) Incidence and patterns of violent and/or traumatic deaths between 1993 and 1999 in the Transkei region of South Africa. J Trauma 57: 125-129.

5. Solagberu BA (2003) Epidemiology and Outcome of Gunshot Injuries in a Civilian Population in West Africa. European Journal of Traumal 29: 92-96.

6. Mohammed AZ, Edina ST, Ochicha O, Umar AB (2005) Epidemiology of gunshot injuries in Kano. Nigerian Journal of Surgical Research 7: 293-296.

7. Onuminya JE, Ohwowhiagbese E (2005) Pattern of civilian gunshot injuries in Irrua, Nigeria. S Afr J Surg 43: 170-172.

8. Udosen AM, Etiuma AU, Ugare GA, Bassey OO (2006) Gunshot injuries in Calabar, Nigeria: an indication of increasing societal violence and police brutality. Afr Health Sci 6: 170-172.

9. Umaru H, Ahidjo A, Madziga A (2005) Highway Armed Robbery: A Major Cause of Extremity Gunshot Injury in North eastern, Nigeria. The Internet Journal of Orthopaedic Surgery 3

10. Abbas AD, Bakari AA, Abba AM (2012) Epidemiology of armed robbery-related gunshot injuries in Maiduguri, Nigeria. Niger J Clin Pract 15: 19-22.

11. Ojo EO, Ibrahim AG, Alabi S, Obiano SK (2008) Gunshot Injuries in A North Eastern Nigerian Tertiary Hospital. The Internet Journal of Surgery 16

12. Obalum DC, Giwa SO, Ogo CN (2007) Pattern of extremity gunshot injuries seen in Lagos University Teaching Hospital, Lagos, Nigeria. Nig Q J Hosp Med 17: $140-143$

13. Ohanaka EC, Iribhogbe EP, Ofoegbu RO (2000) Gunshot injuries in Benin City Nig J of Surg Sc 2: 81-85.

14. Adesanya AA, Afolabi IR, da Rocha-Afodu JT (1998) Civilian abdominal gunshot wounds in Lagos. J R Coll Surg Edinb 43: 230-234.

15. Okobia MN, Osime U (2001) Civilian Gunshot Wounds in Benin City. Nig Medical Pract 39: 67-71.

16. Chamisa I (2011) Pattern of civilian gunshot wounds in Durban, South Africa Eur J Trauma Emerg Surg 37: 37-40.

17. Saheeb BDO, Adeola DS (2004) Craniofacial Gunshot injuries sustained in religious/ethnic riots in Nigeria. Afr J Trauma 2: 88-91.

18. Stefanopoulos PK, Pinialidis DE, Hadjigeorgiou GF, Filippakis KN (2015) Wound ballistics 101: the mechanisms of soft tissue wounding by bullets. Eur J Trauma Emerg Surg.

19. Penn-Barwell JG, Brown KV, Fries CA (2015) High velocity gunshot injuries to the extremities: management on and off the battlefield. Curr Rev Musculoskelet Med 8: 312-317. 